\title{
Research on the Construction of Top-quality Curriculum Resources in Private Applied Undergraduate Universities in the New Era
}

\author{
Baojun $\mathrm{Liu}^{1, *}$
}

\author{
${ }^{1}$ Shandong Huayu University of Technology \\ *Corresponding author. Email: 2460767398@qq.com
}

\begin{abstract}
With the rapid development of Internet technology, network technology has been applied to various industries and fields. In the "Internet +" era, how to use the rich virtual resources of the Internet to effectively construct quality courses is an important topic for private applied undergraduate colleges in the new era. It is necessary to clarify the guiding ideology of constructing high-quality courses, deeply understand its connotation, and carry out scientific planning. Starting from the characteristics of application-oriented undergraduate education, this paper discusses the methods and means of establishing application-oriented high-quality courses in colleges and universities, and strengthens the construction and use of high-quality courses, hoping to provide reference for private application-oriented undergraduate education.
\end{abstract}

Keywords: Application-oriented undergraduate, quality courses, course resources, Internet +

\section{INTRODUCTION}

Application oriented undergraduate education comes into being in the context of the transition of Chinese higher education from elite education to mass education. Application oriented colleges and universities are oriented by social needs and pay more attention to the cultivation of students' practical ability. In the process of constructing excellent courses, combining with the actual situation of Local Application-oriented Universities, we should strengthen the construction of excellent courses, build high-quality scientific practice teaching content, and use online courseware and three-dimensional teaching materials to promote the current traditional way of education reform. Through the construction of excellent courses, students can use the network resources of excellent courses to learn more easily and quickly, promote the improvement of students' information technology level; information technology level, and fully mobilize the enthusiasm and initiative of students.

\section{THE GUIDING IDEOLOGY OF CONSTRUCTING TOP-QUALITY COURSES IN APPLICATION-ORIENTED UNDERGRADUATE COLLEGES}

\subsection{Fully understand the connotation of quality courses}

China's higher education has changed from elite education to mass education. The management mode, management level and the cultivation of talents in higher education have different characteristics. As far as the types of applied talents are concerned, technology-based undergraduate education is different from academic undergraduate education. The main task of academic undergraduate education is to cultivate the ability to explore and discover new principles, study objective laws and transform scientific principles and subject system knowledge into design patterns. Scientific research talents who can further transform design schematic diagram and drawings into products ${ }^{[1]}$. Application oriented universities need to integrate the local actual situation into the construction of excellent courses, so as to promote the effective transformation of theoretical knowledge into productivity. When choosing courses, we must combine the construction of professional disciplines, realize the 
scientific and systematisms of the curriculum system, and pay attention to the relationship between a single course and other courses. Therefore, the teaching of applicationoriented undergraduate courses should meet the needs of cultivating multi type and multi-level applicationoriented talents, and aim to cultivate practical ability, communication ability and innovation ability.

\subsection{Constructing excellent courses in scientific planning}

Application oriented undergraduate teaching should focus on the construction of quality courses, and promote the overall development of the whole discipline by building some quality courses. In the construction of quality courses, there must be a clear timetable, and the course should keep in touch with the relevant courses in the professional curriculum system; the basic characteristics and requirements of the course knowledge system, as well as the knowledge, ability and quality of the relevant working groups should be organically combined to determine the training objectives of the course. According to the overall development strategy of the University, the long-term development goals of each discipline are determined, and then the proportion and level of excellent courses of each discipline are determined $^{[2]}$. The construction of excellent courses should also be planned in stages and layers, and then be upgraded step by step after meeting the requirements of low level, so as to achieve the overall improvement of the teaching level of point-to-point courses.

\subsection{Highlight the features of application- oriented}

Application-oriented undergraduate courses aim to cultivate first-line application-oriented talents, mainly in production, service, technical support, etc., with the focus on cultivating students' skills and abilities, directly applying knowledge rather than discovering knowledge. In the construction of high-quality courses, it is necessary to highlight the characteristics, pay attention to the development of students' application ability, improve students' participation, make students understand the teaching concept and the construction process of highquality courses, and make it a reality. Building excellent courses can not only improve the curriculum system, but also provide better services for students and make them become applied talents to meet the market demand. By using the network teaching resources of high-quality courses, the integration of education and teaching resources in colleges and universities can be effectively realized, and the optimal allocation of high-quality education resources can be realized, so as to improve the teaching quality of colleges and universities and achieve better development and progress. Highlight the characteristics of the training objectives of "applicationoriented" talents.

\section{THE IMPORTANT FACTORS OF CONSTRUCTING EXCELLENT COURSES IN APPLICATION-ORIENTED UNIVERSITIES}

\subsection{Strengthen the construction of teaching staff and attach importance to students' Participation}

First-class teaching staff is an important guarantee for the construction of high-quality courses. The establishment of quality courses is based on the accumulation of long-term teaching and research experience of high-level teachers. The orientation of application-oriented undergraduate talents training goal determines the construction of teaching staff is different from that of ordinary undergraduate colleges and universities. Due to the construction of applicationoriented undergraduate colleges, teachers must have dual qualifications. To reflect the concept of "Double Profession and Double Ability", excellent teachers must not only be able to teach professional theoretical courses, but also have certain practical teaching experience ${ }^{[3]}$. Rich practical teaching experience is the basis of building highquality courses. In the process of building high-quality courses, give full play to the practical experience advantages of enterprise engineers and technicians, let enterprise technicians participate in the development and construction of high-quality courses, record on-site videos, on-site teaching, and realize the real integration of theory with practice.

High-quality application-oriented undergraduate courses should focus on practicality and application, have higher requirements on teachers' practice and internship guidance, be able to grasp the trends in the forefront of discipline and career development, and guide the whole team in teaching and training. It is necessary for teachers to implement the system of "double teachers and double abilities" to adapt to the international teaching law of higher education. In addition, students are the users of quality courses, and students should be the foundation for establishing quality courses. Interviews and surveys can deeply understand the students' orientation of the course and the requirements of teachers' teaching style, so as to continuously improve the construction needs of highquality courses. The construction of network teaching resources of high-quality courses in applied undergraduate colleges aims at providing important reference and guidance for students to learn knowledge. In view of this situation, it is necessary to link students' autonomous learning ability, and do a good job in the construction of curriculum system, so as to provide important reference and guidance for students to learn subject knowledge. For example, the teaching assistant system should be designed in connection with the teaching content, and the basic requirements, main contents, difficult points, example analysis and 
knowledge expansion content should be well grasped, so as to guide students to study and understand the subject knowledge in depth, so as to give play to the function and role of the teaching resources of the fine courses.

\subsection{Enriching educational contents and establishing practical education system}

The key to reform the teaching methods and resources of application-oriented undergraduate course lies in practical teaching. The purpose of the reform is to create a practical environment that combines theory with reality as much as possible, so that students, as the main body of practice, can independently and creatively carry out activities to put theoretical knowledge into practice. In terms of teaching content and expansion, we must fully consider students apos; interests and needs according to students apos; cognitive law. According to students apos; cognitive law, we should constantly introduce the latest research results and industry development trends to students, and guide students to explore and cultivate their autonomous learning ability and innovation ability. The construction of high-quality application-oriented undergraduate courses must reform the subject based curriculum system and establish a comprehensive education system focusing on employment.

\subsection{Improve teaching methods and means}

The premise of constructing excellent courses is to design flexible teaching methods according to different teaching contents. According to different teaching objectives, excellent course teachers should break through the traditional classroom teaching methods and establish a teaching mode that matches the teaching objectives and content system. In the process of implementing the project of "quality management excellent course construction", through grouping the students, using different groups to choose different topics, and discussing the teaching methods of classroom speech outside the classroom, the students apos; participation and learning enthusiasm are greatly improved, which has a good effect in the cultivation of application ability and innovation ability. In order to realize the sustainable development of excellent courses, it is necessary to establish a collection of digital learning materials based on knowledge points, and create an open dynamic multimedia resource library based on the website of excellent courses. Make full use of rich Internet resources, organize the editing of videos related to the course, intuitively display the course content in the course, use the vividness and interest of multimedia courseware teaching to attract students apos; attention, and mobilize their enthusiasm for learning and using information $^{[4]}$. In addition, application-oriented universities should ensure the necessary investment in the construction of excellent courses, so that the excellent course construction team can use it for the construction and daily maintenance of course website, and provide technical support for the establishment of excellent course website, so as to promote the practicability of the content of excellent course website.

\subsection{Pay attention to the construction of teaching materials}

Textbooks are the support of the construction of excellent courses ${ }^{[5]}$. The selection of textbooks should be scientific and rigorous, and constantly updated. As part of the teaching content, students' interests should be taken into account, and the latest research results and research trends in this field should be continuously communicated and discussed with students, so as to improve students' active participation consciousness and ability of independent learning and innovation. In the course of teaching material construction, quality courses should pay attention to the effective grasp of reference materials, practice materials, learning instructions, teachers' teaching courseware and other contents, so as to improve the quality of integrated development of teaching materials and provide important reference for students in application-oriented universities to learn knowledge ${ }^{[6]}$. It is necessary to pay attention to the relationship between students' professional development characteristics and learning characteristics, combine the needs of students' professional development and future employment development needs, highlight the richness, practicability and technology of teaching materials resources, provide effective guidance for students to learn professional knowledge, and realize the sharing of high-quality education and teaching resources.

\subsection{Innovating Curriculum Management Mechanism}

In order to ensure the efficiency of excellent course construction, we must establish a strong management mechanism, through self-management and mutual supervision, to promote the long-term development of high-quality excellent course construction. Establish the responsibility division system, reasonably organize the work and behavior of the lecturer, practice lecturer and website construction teacher in the excellent course, and assume clear responsibilities within the framework of mutual cooperation. To establish a management mechanism, adhere to the principles of fairness, justice and openness, effectively ensure the quality of quality courses; incentive mechanism can improve the enthusiasm of teachers, and give priority to the teachers participating in the construction of quality courses from the perspective of the use of funds, annual evaluation and professional designated evaluation; The management and supervision mechanism of excellent courses can be composed of members of Academic Committee of the school, Academic Committee Process planning sequence check the construction progress of quality courses, pay 
attention to the quality of quality courses, find problems and correct them in time. At the same time, we should establish a quality evaluation system with self-evaluation as the pillar and external evaluation as the supplement, strengthen internal and external evaluation and supervision, and promote training quality courses.

\section{CONCLUSION}

Under the new education teaching development, run by the applied undergraduate education in colleges and universities teaching in the new period should base on the education informatization development situation, exert the resource advantage of private applied undergraduate colleges and universities at present stage and education force, work to strengthen the construction of high-quality goods curriculum resources, to provide important reference and guidance for students to study knowledge, improve the quality of teaching. The construction of high-quality course resources in application-oriented universities should pay attention to the following points:

(1) Strengthen the construction and management of teachers, attach importance to the degree of student participation, and improve the construction and utilization of students' participation in high-quality courses.

(2) Enrich educational content, establish a practical education system, integrate with enterprises, deepen school-enterprise cooperation, and increase the integration of industry and education.

(3) Improve teaching methods and means, innovate teaching methods, and improve the level of informationbased teaching.

(4) Pay attention to the construction of teaching materials, build first-class teaching materials, use planning high-quality teaching materials.

(5) Innovate the course management mechanism, establish an effective supervision and management mechanism, improve the utilization rate of quality courses, and maintain the lasting vitality of quality courses.

Application oriented colleges and universities should focus on cultivating application-oriented talents, formulate overall planning, and strictly implement the goal of building first-class quality courses. Excellent courses should be regarded as system engineering and quality engineering, which is an important part of promoting the construction and development of other courses and a solid foundation for improving the quality of education and talents. The application-oriented undergraduate students should aim at cultivating "service-oriented, employment-oriented, front-line technical talents needed by the development of society", give play to the exemplary role of excellent courses, promote the quality construction, stimulate the development of disciplines and majors, and lay the foundation for the private application-oriented undergraduate colleges to cultivate technical talents necessary for local social and economic development in the new era.

\section{ACKNOWLEDGMENTS}

Research results of the 2019 school level education and teaching reform research project of Shandong Huayu Institute of technology "Research on the construction of excellent courses in application-oriented universities in the new era" (2019ZD07).

\section{REFERENCES}

[1] He Yongqiang, Zhang Shunli. Exploration on the construction of excellent courses in Local Application-oriented Universities [J]. Quality education in Western China, 2017,3 (12): 101-103.

[2] Luo Xuelian. A review of the research on excellent courses in Colleges and universities [J]. Modern educational science, 2010, (1): 58-60.

[3] Xiang Cong. Optimization strategy of excellent course resources construction $[\mathrm{J}]$. China education informatization, 2008, (15): 8-10.

[4] Feng Boqin, Zheng Qinghua. Construction of computer excellent resource contribution course and exploration of collaborative innovation mode [J]. China University Education, 2013, (8): 8-11.

[5] Fang Min. Teaching Materials Construction for Applied Universities [J]. Modern Vocational Education,2018, (04).

[6] Xu Yaqiang. Analysis on the Construction of National Excellent Curriculum [J]. Development, 2008, (7): 117-117. 